\title{
Seasonal variations in biomass, growth rate and production rate of the small cyclopoid copepod Oithona davisae in a temperate eutrophic inlet
}

\author{
Shin-ichi Uye*, Kazuhiro Sano \\ Faculty of Applied Biological Science, Hiroshima University, 4-4 Kagamiyama 1 Chome, Higashi-Hiroshima 739-8528, Japan
}

\begin{abstract}
We investigated the seasonal variations in biomass, somatic growth rate and production rate of the small cyclopoid copepod Oithona davisae in Fukuyama Harbor, a eutrophic inlet of the Inland Sea of Japan. The carbon biomass of the population, excluding nauplii, was lowest in early spring and increased exponentially in early summer to a maximum of $92.2 \mathrm{mg} \mathrm{m}^{-3}$ in mid-June. Thereafter, it was relatively high, except for a mid-summer decline, until fall. The specific growth rates of naupliar and copepodite stages were estimated from their body weight increments and stage durations, assuming that in this highly eutrophic inlet growth is food-satiated for this species. They increased exponentially with increasing temperature, ranging from 0.088 to $0.357 \mathrm{~d}^{-1}$ for nauplii and from 0.060 to $0.446 \mathrm{~d}^{-1}$ for copepodites within the annual temperature range of 8.9 to $28.2^{\circ} \mathrm{C}$. The production rate as a sum of somatic growth rate of copepodites and egg production rate of adult females varied similarly to, but showed a wider range than, the biomass variation. Annual integrated carbon production was $650 \mathrm{mg} \mathrm{m}^{-3} \mathrm{yr}^{-1}$, or $4.88 \mathrm{~g} \mathrm{~m}^{-2} \mathrm{yr}^{-1}, 94 \%$ of which was attained between June and October. Of the production, copepodite somatic growth and female egg production comprised 75 and $25 \%$, respectively. O. davisae contributed $26 \%$ of the annual copepod community production in Fukuyama Harbor.
\end{abstract}

KEY WORDS: Biomass - Growth · Production C Cyclopoid Oithona Inland Sea of Japan

\section{INTRODUCTION}

Oithonids are the most successful free-living cyclopoids in the marine pelagic ecosystem. They are small, usually $<1.0 \mathrm{~mm}$ in body length, but they occur ubiquitously in the epipelagic and mesopelagic layers of the world oceans at relatively high numerical densities (Boxshall 1977, Nishida 1985, Böttger-Schnack et al. 1989). Although information on their biology and ecology has been accumulated recently (cf. Turner 1986 , Uchima 1988, Paffenhöfer 1993, Sabatini \& Kiørboe 1994, Nielsen \& Sabatini 1996, Nakamura \& Turner 1997), much less is known of their ecological importance, compared to calanoid copepods (cf. Huntley \& Lopez 1992). In order to understand the functional role of the oithonids in the marine ecosystem, it is necessary to accumulate quantitative information on their biomass, feeding, growth, production, metabolism, predation loss, etc.

\footnotetext{
•E-mail: suye@ipc.hiroshima-u.ac.jp
}

Among oithonids, Oithona davisae and $O$. similis have been studied most extensively. The former is distributed in the coastal waters of southwestern Japan (Nishida 1985) and in the Sacramento-San Joaquin estuary, California, USA (Ferrari \& Orsi 1984). It often comprises the most abundant copepod in eutrophic embayments such as in Tokyo Bay (Nagasawa \& Marumo 1984, Uye 1994), Hiroshima Bay (Uye et al. 1992) and Ariake Bay (Hirota \& Tanaka 1985, Hirota 1990). The latter species occurs very widely from temperate to polar seas, even in oligotrophic oceanic waters (Shuvalov 1975, Fransz \& Gonzalez 1995). In many inlet waters along Japan, these 2 species cooccur. Generally, $O$. davisae is much more abundant than $O$. similis, particularly in the inner part of inlets during summer and fall, and the latter is distributed mainly in the outer part of inlets during winter and spring (Yamazi 1956, Ueda 1991).

During the studies on the population dynamics and production of major copepod species in Fukuyama Harbor, a eutrophic inlet located in the central part of 
the Inland Sea of Japan (Liang \& Uye 1996a, b, 1997 , Liang et al. 1996), we found that Oithona davisae was the most numerous species among 12 identified copepod species occurring in this inlet (Uye \& Liang in press). The seasonal reproductive biology of this species was reported elsewhere (Uye \& Sano 1995). In this paper, we describe the seasonal variations in biomass, juvenile somatic growth rate and population production rate, in order to assess the trophodynamic role of this species in the temperate coastal marine ecosystem. Some characteristic properties of $O$. davisae are compared to those of other oithonid species, particularly $O$. similis.

\section{MATERIAL AND METHODS}

Sampling. Oithona davisae were collected by oblique tows of a plankton net (mouth diameter: $0.45 \mathrm{~m}$; length: $2.0 \mathrm{~m}$; mesh opening: $62 \mu \mathrm{m}$; with a flowmeter) from the bottom (depth: 7 to $8 \mathrm{~m}$ ) to the surface at intervals of 3 to $5 \mathrm{~d}$ from 7 November 1986 to 8 November 1987 at a station in Fukuyama Harbor (see Uye \& Sano 1995). Samples were taken around the time of full tide during the night (between 17:00 and 07:00 h) to reduce possible variability of abundance caused by patchy distribution (Landry 1978, Ueda 1987) and tidal cycle (Sameoto 1975, Lee \& McAlice 1979). The samples were preserved immediately in 5 to $10 \%$ formalin-seawater solution. Temperature and salinity at $1 \mathrm{~m}$ depth were measured with a thermo- and salinometer (YSI, Model 33). The surface water (50 to $200 \mathrm{ml}$ ) was filtered with a glassfiber filter (Whatman GF/C) for later determination of extracted (with $90 \%$ aqueous acetone) chlorophyll a concentration with a fluorometer (Turner Designs, Model 10).

Biomass. Adult females, males and copepodites of Oithona davisae from split sub-samples (1/16 to $1 / 258$ of original samples) were counted under a dissecting microscope, but nauplii were not counted since they were not retained in sufficient numbers by our net. Prosome length was measured to the nearest $5 \mu \mathrm{m}$ using a video micrometer (Olympus, VM-10) for 50 randomly selected females and 100 copepodites from each sample, and for 50 males from samples collected on the first sampling date of each month. Prosome length of males on the other sampling dates was estimated from the mean prosome length-temperature relationship (see 'Results').

To convert from prosome length to individual carbon weight, it was necessary to establish a length-weight relationship. For this, we determined the body volume of different developmental stages by measuring the following body parts to the nearest $0.8 \mu \mathrm{m}$ using an eye-piece micrometer: (1) length, width and height of prosome, (2) length and width of each urosome segment, and (3) length and width of first antenna, assuming that the prosome is shaped as a depressed ellipsoid, and the urosome segments and first antenna are cylindrical. The volume of the labrum and the other appendages was not included. We thereby obtained a prosome length-body volume relationship (see 'Results'). Mean carbon weight per unit volume was calculated from 5 actual measurements of carbon weight and prosome length (Uye 1982), and was used to convert from volume data to carbon weights. Finally, the carbon weight data were regressed on prosome length (see 'Results').

Growth rate. Uchima (1985) successfully reared Oithona davisae from Tokyo Bay under food-satiated laboratory conditions and demonstrated the temperature-dependent development from spawning to NI, CI and adult. According to his data, $O$, davisae showed almost equiproportional development (Corkett 1984); the proportions of the naupliar and copepodite duration to the egg duration were 5.70 and 4.16 , respectively. In our previous study (Uye \& Sano 1995) using O. davisae from Kure Harbor, Inland Sea of Japan, the relationship between egg development time $\left(D_{E}\right.$, in days) and temperature $\left(T,{ }^{\circ} \mathrm{C}\right)$ was presented:

$$
D_{\mathrm{E}}=1.31 \times 10^{4} \times(T+12.3)^{-260} \quad(\mathrm{r}=0.996)
$$

Assuming the same equiproportional development, the following Bělehrádek's functions to describe the duration of the naupliar and copepodite stages $\left(D_{\mathrm{N}}\right.$ and $D_{\mathrm{C}}$, in days) in relation to temperature were given for Oithona davisae in the Inland Sea of Japan (Fig. 1):

$$
\begin{aligned}
& D_{\mathrm{N}}=7.47 \times 10^{4} \times(T+12.3)^{-260} \\
& D_{\mathrm{C}}=5.45 \times 10^{4} \times(T+12.3)^{-2.60}
\end{aligned}
$$

Assuming no food limitation, the average specific growth rates over naupliar and copepodite stages $\left(g_{\mathrm{N}}\right.$ and $g_{C}, d^{-1}$ ) are then, respectively:

$$
\begin{aligned}
& g_{N}=\left(\ln C_{C I}-\ln C_{E}\right) / D_{N} \\
& g_{C}=\left(\ln C_{C V I}-\ln C_{C I}\right) / D_{C}
\end{aligned}
$$

where $C_{E}, C_{C I}$ and $C_{C V I}$ are carbon weights of an egg (e.g. 7.38 ng; Uye \& Sano 1995), CI and adult, respectively, and $D_{\mathrm{N}}$ and $D_{\mathrm{C}}$ are the durations of the naupliar and copepodite stages, respectively, which were calculated from Eqs. (2) \& (3) by substituting the water temperature on the sampling date.

Production rate. The carbon production rate of copepodites of Oithona davisae $\left(P_{\mathrm{C}}, \mathrm{mg} \mathrm{m}^{-3} \mathrm{~d}^{-1}\right)$ was given by:

$$
P_{C}=B_{C} \times g_{C}
$$

where $B_{C}\left(\mathrm{mg} \mathrm{m}^{-3}\right)$ is carbon biomass of copepodites. The production rate of females $\left(P_{\mathrm{F}}, \mathrm{mg} \mathrm{m}^{-3} \mathrm{~d}^{-1}\right)$ was given by: 


$$
P_{\mathrm{F}}=B_{\mathrm{F}} \times g_{\mathrm{F}}
$$

where $B_{\mathrm{F}}\left(\mathrm{mg} \mathrm{m}^{-3}\right)$ and $g_{\mathrm{F}}\left(\mathrm{d}^{-1}\right)$ are biomass and specific egg production rate of females (on population average basis), respectively. The latter parameter had already been reported in our previous paper (Uye \& Sano 1995). Hence, the production rate of $O$. davisae population older than $\mathrm{CI}\left(P, \mathrm{mg} \mathrm{m}^{-3} \mathrm{~d}^{-1}\right)$ was given as a sum of $P_{\mathrm{C}}$ and $P_{\mathrm{F}}$. The production of adult males was assumed to be negligible.

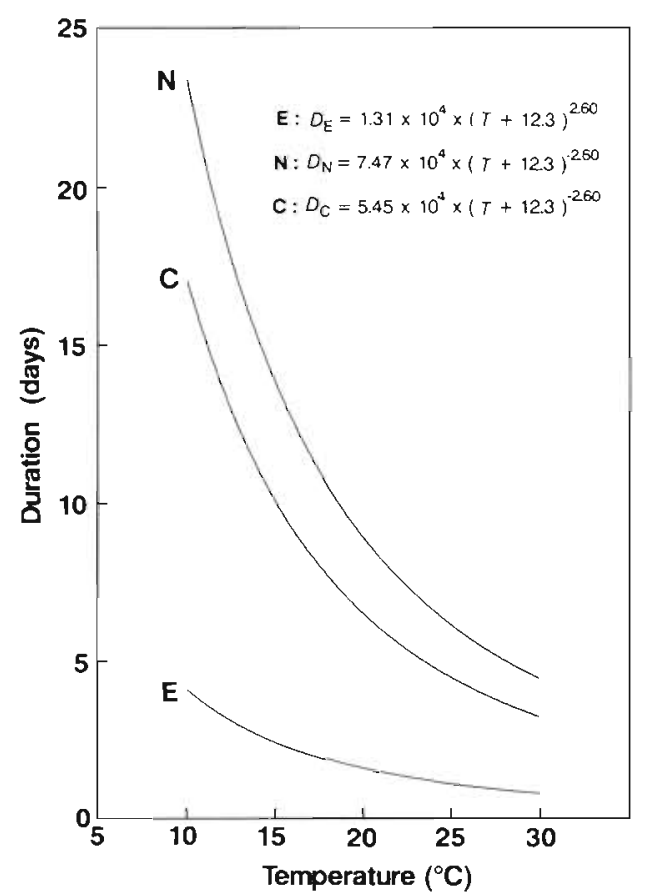

Fig. 1. Oithona davisae. Relationship between temperature $(T)$ and duration $(D)$ of egg $(E)$, naupliar stages $(N)$ and copepodite stages (C). Egg duration was determined for specimens from Kure Harbor, the Inland Sea of Japan (Uye \& Sano 1995). Naupliar and copepodite durations were predicted by applying the equiproportional development observed for specimens from Tokyo Bay (Uchima 1985)

\section{RESULTS}

\section{Prosome length-carbon weight relationship}

The body volume of different copepodite stages including adults $\left(V, \mu \mathrm{m}^{3}\right)$ increased exponentially with the increase of prosome length $(P L, \mu \mathrm{m})$ :

$$
V=33.7 \times P L^{1.96} \quad(\mathrm{r}=0.993)
$$

The mean body carbon weight per unit volume calculated from the 5 measurements from Uye (1982) for adults was $8.34 \times 10^{-8} \mu \mathrm{g} \mathrm{\mu m}^{-3}$ and was used to esti-

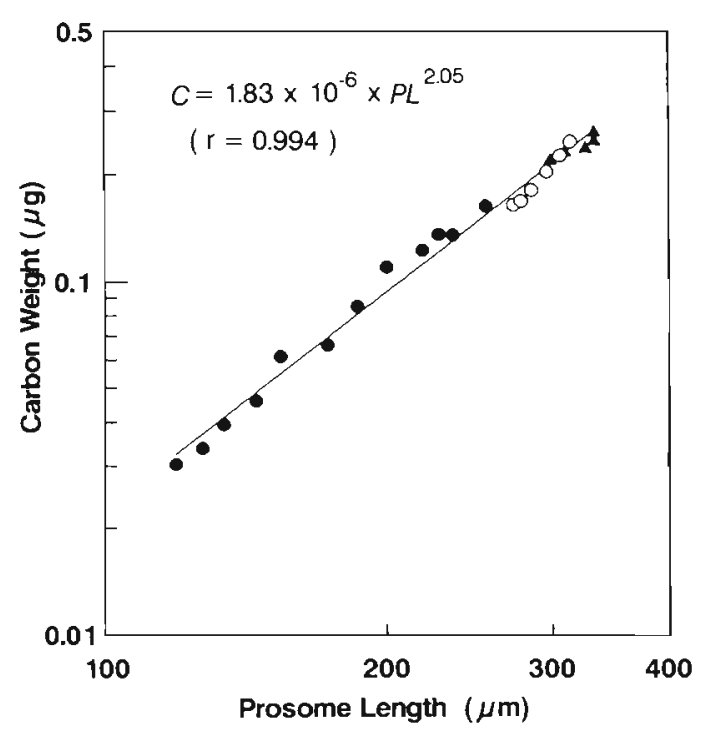

Fig. 2. Oithona davisae. Relationship between prosome length $(P L)$ and carbon weight of copepodites ( ) and adults (O). Data for adults (4) from Uye (1982) are also included in the regression equation

mate the carbon weights of different stages. The converted carbon weights $(C, \mu \mathrm{g})$ were plotted against prosome lengths including the above 5 data points (Fig. 2). The regression equation for all data points was:

$$
C=1.83 \times 10^{-6} \times P L^{205} \quad(\mathrm{r}=0.994)
$$

\section{Seasonal variation in environmental variables}

Temperature varied from $8.9^{\circ} \mathrm{C}$ on 2 March to $28.2^{\circ} \mathrm{C}$ on 11 September (Fig. 3). Salinity ranged from 28.6 to $32.3 \%$ and was lower and more variable in summer and fall than in winter and spring. Chlorophyll $a$ concentration varied very widely from 0.70 to $322 \mu \mathrm{g} \mathrm{l^{-1 }}$. Extraordinarily high chlorophyll a values were due to occurrence of red tides of Chattonella marina and Heterosigma akashiwo (both Raphidophyceae).

\section{Seasonal variation in abundance}

As shown in Fig. 4, the abundance of Oithona davisae was lowest in early spring (mean density in March and April: $3.5 \times 10^{3}$ females $\mathrm{m}^{-3}, 9.2 \times 10^{2}$ males $\mathrm{m}^{-3}$ and $6.5 \times 10^{2}$ copepodites $\mathrm{m}^{-3}$ ). From mid-May to mid-June, it increased exponentially, to attain the annual peak $\left(24.6 \times 10^{4}\right.$ females $\mathrm{m}^{-3}, 5.49 \times 10^{4}$ males $\mathrm{m}^{-3}$ and $29.8 \times 10^{4}$ copepodites $\mathrm{m}^{-3}$ ) on 18 June. The abundance remained high, but fluctuating, until mid- 


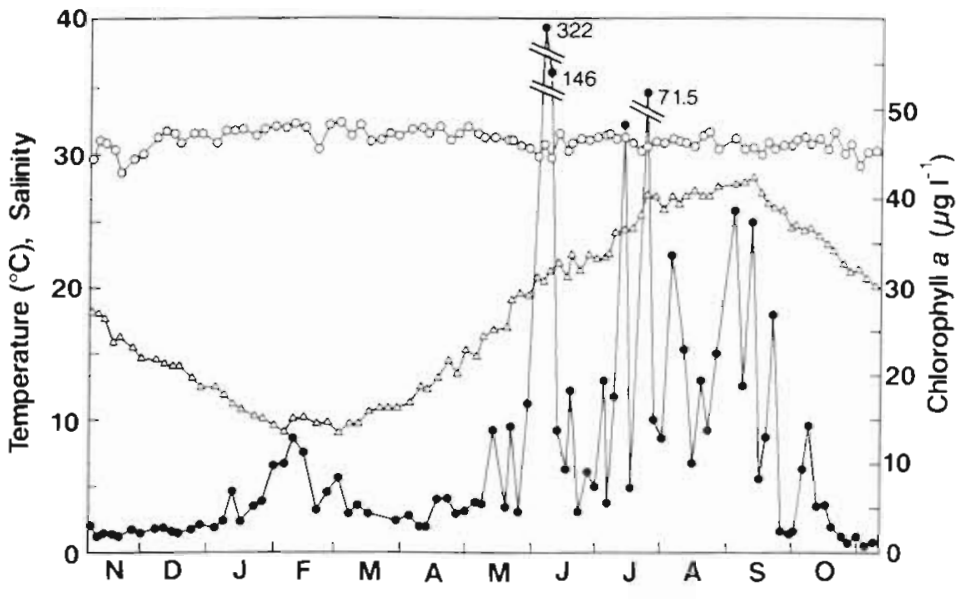

Fig. 3. Seasonal variations in temperature $(\Delta)$, salinity $(0)$ and chlorophyll a concentration ( $\bullet$ ) in Fukuyama Harbor

July; thereafter it declined to a mid-summer minimum. The population increased again in early September to form the fall peak, after which it declined gradually until late winter

\section{Seasonal variation in prosome length}

The prosome lengths of females, males and $\mathrm{CI}$ showed a similar seasonal trend, being largest in early spring and smallest in mid-summer (Fig. 5). The relationship between prosome lengths of these stages $\left(P L_{\Gamma,}\right.$. $P L_{y}$ and $P L_{C I}, \mu \mathrm{m}$ ) and temperature gave the following negative linear regressions:

$$
\begin{array}{rlrl}
P L_{\mathrm{F}} & =344-2.23 T & & (\mathrm{r}=-0.922) \\
P L_{\mathrm{M}}=328-1.94 T & & (\mathrm{r}=-0.914) \\
P L_{\mathrm{Cl}} & =199-2.40 T & & (\mathrm{r}=-0.946)
\end{array}
$$

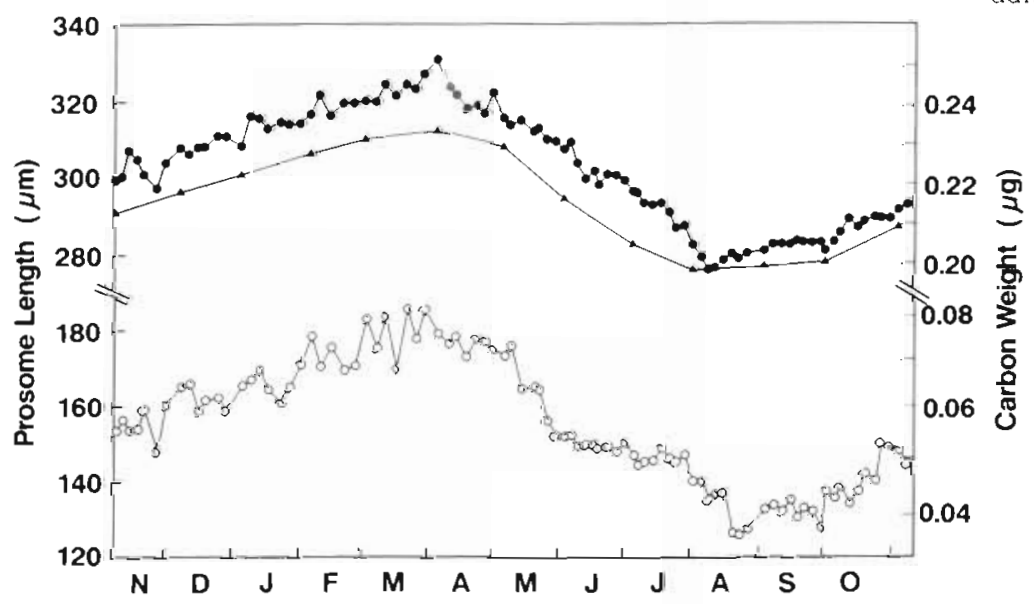

Fig. 5. Oithona davisae. Seasonal variation in mean prosome length and carbon weight of females (•), males $(\mathbf{\Lambda})$ and $\mathrm{Cl}(0)$ in Fukuyama Harbor

\section{Seasonal variation in growth rate}

The potential growth rates of both nauplii and copepodites were highest in summer and lowest in winter (Fig. 6). The growth rate of nauplij was slightly higher than that of copepodites in winter and spring, but it was vice versa in summer. The minimum growth rates were 0.088 and $0.060 \mathrm{~d}^{-1}$ for nauplii and copepodites, respectively, both recorded on $5 \mathrm{Feb}-$ ruary. The maximum rates were 0.357 and $0.446 \mathrm{~d}^{-1}$ for nauplii (on 28 July) and copepodites (on 11 September), respectively.

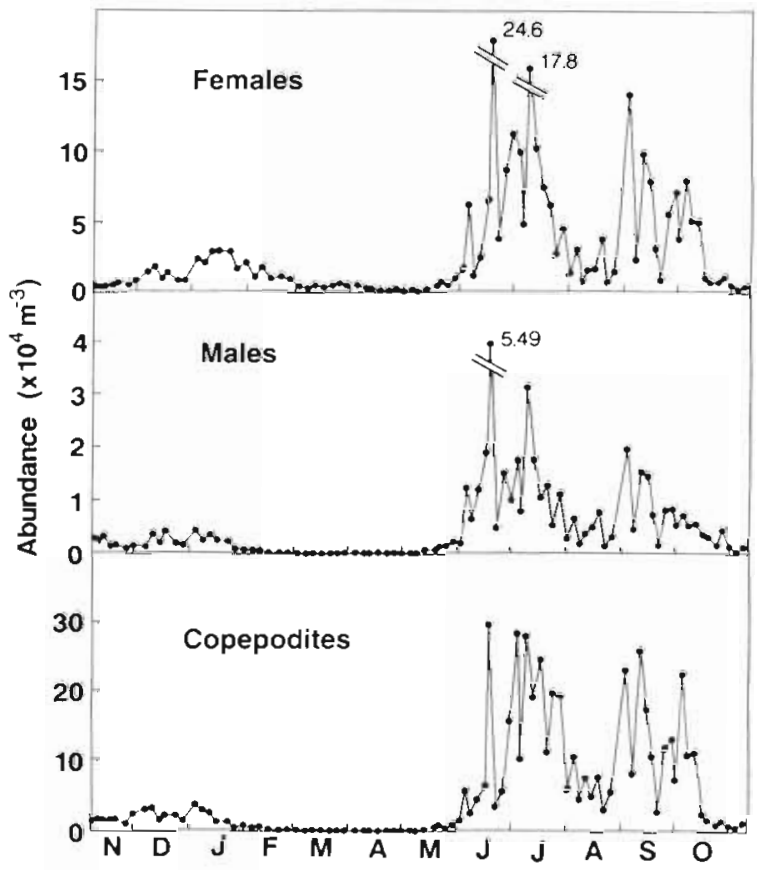

Fig. 4. Oithona davisae. Seasonal variation in abundance of females, males and copepodites in Fukuyama Harbor

\section{Seasonal variation in biomass}

The biomass of females, males and copepodites of Oithona davisae varied markedly with season (Fig. 7), largely reflecting their numerical variation. The total biomass was lowest in March and April, with a mean biomass of $2.18 \mathrm{mg}$ $\mathrm{m}^{-3}$ It increased significantly between mid-May and mid-June and the maximum biomass (92.2 $\mathrm{mg} \mathrm{m}^{-3}$ ) was attained on 18 June. The biomass remained high in early summer and early fall, but decreased in mid-summer 


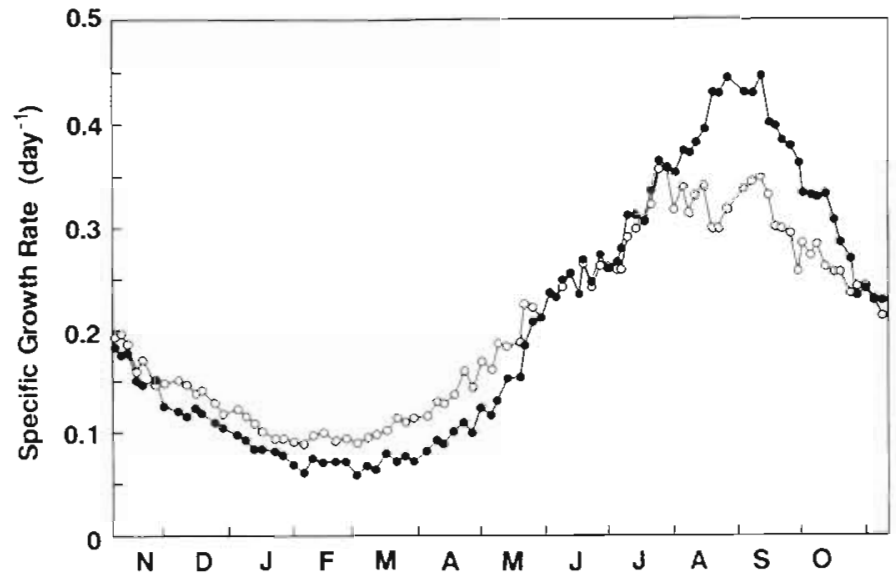

Fig. 6. Oithona davisae. Seasonal variation in growth rate of naupliar stages (0) and copepodite stages (•) in Fukuyama Harbor

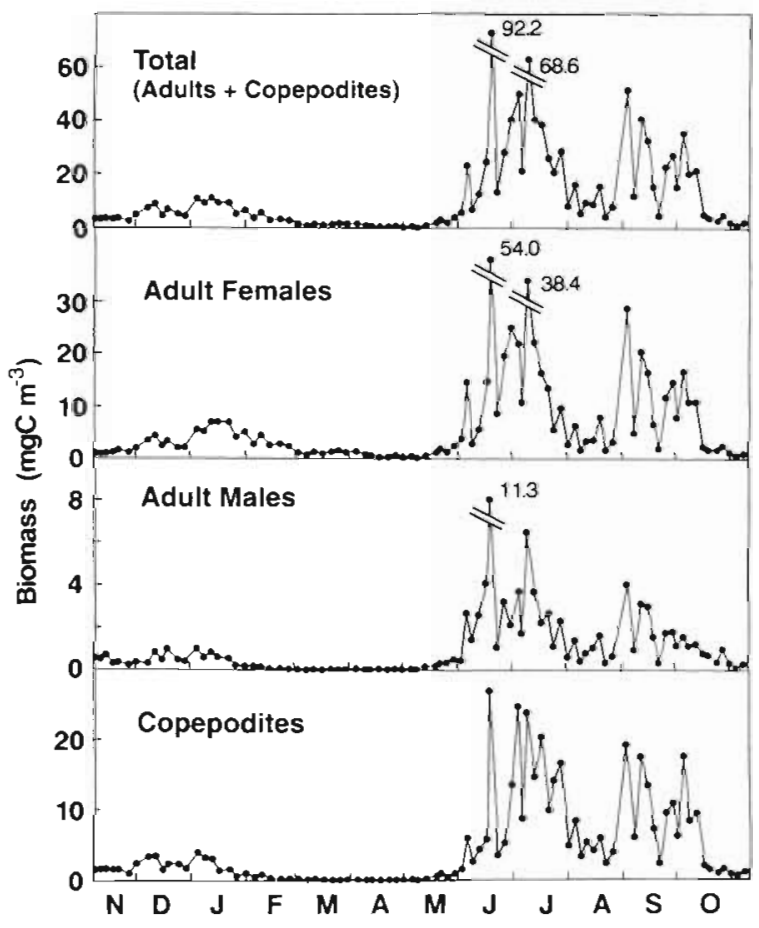

Fig. 7. Oithona davisae. Seasonal variation in total biomass and biomass of adult females, adult males and copepodites in Fukuyama Harbor

\section{Seasonal variation in production rate}

The pattern of seasonal variation in potential production rate (Fig. 8) was essentially similar to, but showed a wider range than, that of variation in biomass. The production rate between February and April was extremely low, with a mean of $0.041 \mathrm{mg} \mathrm{m}^{-3} \mathrm{~d}^{-1}$. The annual maximum (10.9 $\left.\mathrm{mg} \mathrm{m}^{-3} \mathrm{~d}^{-1}\right)$ was recorded

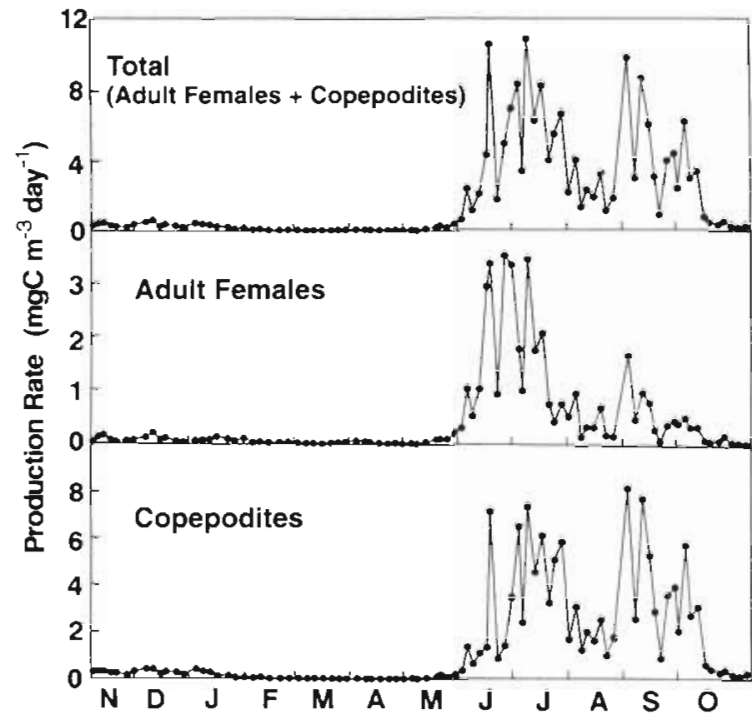

Fig. 8. Oithona davisae. Seasonal variation in total production rate and production rates of adult females and copepodites in Fukuyama Harbor

on 9 July. Annual integrated production was $650 \mathrm{mg}$ $\mathrm{m}^{-3} \mathrm{yr}^{-1}$, or $4.88 \mathrm{~g} \mathrm{~m}^{-2} \mathrm{yr}^{-1}, 94 \%$ of which was attained between June and October. Of the production, copepodite somatic growth and female egg production accounted for 75 and $25 \%$, respectively.

\section{DISCUSSION}

The seasonal variation in abundance of Oithona davisae in Fukuyama Harbor was strikingly large. Such a variation is attributed to the balance between population birth rate and death rate; the former can be predicted from the population egg production rate. As demonstrated previously (Uye \& Sano 1995), the population egg production rate was extremely low in winter and spring, increased exponentially in May and early June, and attained its maximum shortly afterwards. A large numerical peak $\left(5.98 \times 10^{5}\right.$ adults and copepodites $\mathrm{m}^{-3}$ ) recorded in mid-June was the culmination of increased egg production rate and number of adult females. This water-column average density was probably the highest reported so far for this species except for swarm density (i.e. $1.34 \times 10^{6}$ ind $\mathrm{m}^{-3}$ ) recorded on the mud flat of Ariake Bay, Kyushu (Hirota \& Tanaka 1985). After mid-July, the population decreased sharply to a mid-summer minimum due to a decrease in the number of adult females, whereas the egg production rate did not decline significantly until the end of August (Uye \& Sano 1995). The mid-summer decline of the population was due probably to the predation by the lobate ctenophore Bolinopsis mikado, which was present from July to September with a peak abun- 
dance in August as indicated by the numbers of comb plates which remained in the plankton samples (Uye \& Liang in press).

One of the reasons why Oithona davisae was so abundant in Fukuyama Harbor might be a sufficient food supply. The potential food for this species may be flagellates (both autotrophic and heterotrophic), ciliates and copepod nauplii, according to Uchima (1988) and Uchima \& Hirano (1986a, b). A slight interspecific difference can be seen in the feeding habit of the oithonids. For example, no diatoms are found in the gut of $O$. davisae (Uchima 1988), although they are the major components of the gut contents of $O$. similis (Hopkins \& Torres 1989), O. plumifera and O. simplex (Turner 1986). González \& Smetacek (1994) found that $O$. similis can also utilize zooplankton fecal pellets. Paffenhöfer (1993) demonstrated that O. plumifera does not generate a feeding current, unlike the feeding mechanism of suspension-feeding calanoids, and speculated that the hydrodynamic signals from the prey allow oithonids to perceive food particles. The importance of motile prey as food for oithonids has been confirmed by not only the studies with $O$. davisae (Uchima \& Hirano 1986a, b, Uchima 1988) but also by recent studies dealing mainly with $O$. similis (Sabatini \& Kiørboe 1994, Nielsen \& Sabatini 1996, Nakamura \& Turner 1997). Nielsen \& Sabatini (1996) investigated the temporal and spatial variations in the biomass and egg production rate of Oithona spp. (mainly O. similis) in the Dogger Bank region, North Sea. The variations in biomass and egg production rate of Oithona spp. were much less than those of the co-occurring calanoids, where variation was primarily dependent on phytoplankton food availability. The egg production rate of $O$. similis was positively correlated at a significant level only to the abundance of naked dinoflagellates. Based on this correlation in O. similis, Nielsen \& Sabatini (1996) speculated that Oithona spp. were associated with microbial food webs.

Although the food availability for Oithona davisae in Fukuyama Harbor was not quantified in this study, flagellates were apparently the main components of phytoplankton at least in summer, as in other eutrophic embayments in Japan (Yamaguchi \& Aruga 1988). The 2 raphidophycids Chattonella marina and Heterosigma akashiwo, which formed red tides in June and July, could also be utilized by $O$, davisae (Uchima \& Hirano 1986a). Given the high chlorophyll a concentrations in this heavily eutrophic inlet, the assumption of food-satiated growth of this species was likely justified, at least during its main productive seasons (i.e. from June to October). The food-satiated egg production rates observed for 2 calanoids, Paracalanus sp. and Pseudodiaptomus marinus, in Fukuyama Harbor (Uye \& Shibuno 1992, Liang \& Uye 1997) provide supportive evidence for this assumption, although, as mentioned above, the feeding habits of these species are not exactly the same as for $O$. davisae.

In this study, we did not determine the postembryonic development time for Oithona davisae from Fukuyama Harbor, but estimated it by applying the rule of equiproportional development observed for $O$. davisae from Tokyo Bay (Uchima 1985). Since this development mode is achieved only under food-satiated conditions (Corkett 1984), it may be applicable to the population in Fukuyama Harbor. Due to differences in the relation of egg development times to temperature between the population of Tokyo Bay $\left(D_{\mathrm{E}}=\right.$ $9.84 \times 10^{2} \times(T+3.0)^{-205}$; Uchima 1985) and the population of the Inland Sea of Japan (see Eq. 1), the computed durations from egg to adult were slightly different particularly at lower temperatures; they were 56.2, 17.2 and $8.2 \mathrm{~d}$ at 10,20 and $30^{\circ} \mathrm{C}$, respectively, for the former, and 44.4, 17.0 and $8.4 \mathrm{~d}$ for the latter.

As the stage duration decreased exponentially with temperature (Fig. 1), the potential growth rates during naupliar and copepodite stages $\left(g_{\mathrm{N}}\right.$ and $\left.g_{\mathrm{C}}, \mathrm{d}^{-1}\right)$ increased exponentially with temperature (Fig. 9):

$$
\begin{array}{ll}
g_{N}=5.11 \times 10^{-2} \times \mathrm{e}^{00708 T} & (\mathrm{r}=0.988) \\
g_{\mathrm{C}}=2.66 \times 10^{-2} \times \mathrm{e}^{0.103 T} & (\mathrm{r}=0.995)
\end{array}
$$

The potential growth rate, as represented by egg production rate, of ovigerous females (Uye \& Sano 1995) was also plotted against temperature (Fig. 9). Since the egg production rate $\left(g_{\mathrm{F}}, \mathrm{d}^{-1}\right)$ did not increase

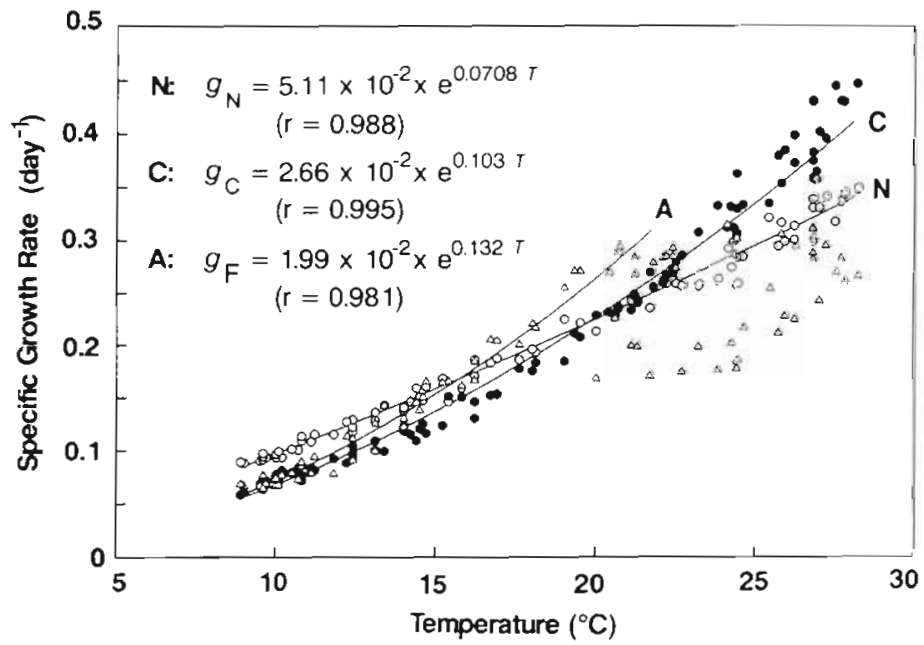

Fig. 9. Oithona davisae. Relationship between growth rate of naupliar stages $(\mathrm{N}, \mathrm{O})$, copepodite stages $(\mathrm{C}, \bullet)$ and continuously reproducing females $(F, \Delta)$ and temperature. The growth rate of females was substituted by egg production rate at temperatures $<22^{\circ} \mathrm{C}$ (Uye \& Sano 1995) 
or was even reduced at temperatures $>22^{\circ} \mathrm{C}$ (Uye \& Sano 1995), the following exponential relation was obtained at temperatures $<22^{\circ} \mathrm{C}$ :

$$
g_{\mathrm{F}}=1.99 \times 10^{2} \times \mathrm{e}^{0.132 T} \quad(\mathrm{r}=0.981)
$$

Fig. 9 demonstrates that there was no discernible difference in the potential specific growth rate between naupliar, copepodite and adult (i.e. continuously reproducing female) stages; hence we conclude that the growth rate was largely uniform throughout the life stages for this species at temperatures between ca 9 and $22^{\circ} \mathrm{C}$ under food-satiated conditions.

Sabatini \& Kiørboe (1994) examined the somatic growth rate and egg production rate of Oithona similis from Øresund, Denmark, under food-satiated laboratory conditions at $15^{\circ} \mathrm{C}$. The potential growth rate from NII to CIV was $0.20 \mathrm{~d}^{-1}$, slightly higher than that of $O$. davisae $\left(0.15\right.$ and $0.12 \mathrm{~d}^{-1}$ for nauplii and copepodites, respectively) and it decreased to $0.07 \mathrm{~d}^{-1}$ after CIV. The maximum specific egg production rate of $O$. similis was $0.10 \mathrm{~d}^{-1}$, slightly lower than that of $O$. davisae $\left(0.14 \mathrm{~d}^{-1}\right)$. These comparisons made us conclude that under food-satiated conditions the specific somatic and egg production rates of these 2 species are roughly comparable at $15^{\circ} \mathrm{C}$.

The thermophylic nature of Oithona davisae was particularly conspicuous in its production rate, and hence $94 \%$ of the annual production was attained between June and October, when the temperature was $>20^{\circ} \mathrm{C}$. Although the production rate of its nauplii was not included in this study, it is apparently much lower than that of older stages (Mullin 1988). The contribution made by somatic growth of copepodites was most important (i.e. $75 \%$ ) in the total production rate. The annual carbon production of the total copepod community, which consisted of 12 species, was estimated as $2.50 \mathrm{~g} \mathrm{~m}^{-3} \mathrm{yr}^{-1}$ or $18.4 \mathrm{~g} \mathrm{~m}^{-2} \mathrm{yr}^{-1}$, to which Paracalanus sp., O. davisae, Acartia omorii and Centropages abdominalis contributed $27,26,25$ and $15 \%$, respectively (Uye \& Liang in press).

In summary, the small cyclopoid copepod Oithona davisae comprised the most abundant copepod species in early summer in eutrophic Fukuyama Harbor. Assuming food-satiated conditions in this eutrophic harbor, the temperature-dependent somatic growth rate of $O$. davisae was determined. The specific rates for both somatic growth and egg production were roughly comparable at temperatures between ca 9 and $22^{\circ} \mathrm{C}$. Due to high biomass coupled with high growth rate, $94 \%$ of the annual population production ( $650 \mathrm{mg} \mathrm{m}^{-3} \mathrm{yr}^{-1}$ ) was attained between June and October. These results indicate that $O$. davisae may play a significant role in transferring the energy from nano- and microflagellates and ciliates to higher trophic levels in warm seasons in eutrophic embayments along the Japanese coasts.
Acknowledgements. We thank Drs T Onbe and J. T Turner for constructive comments on this manuscript. We also thank anonymous reviewers for helpful comments.

\section{LITERATURE CITED}

Böttger-Schnack R, Schnack D, Weikert H (1989) Biological observations on small cyclopoid copepods in the Red Sea. J Plankton Res 11:1089-1101

Boxshall GA (1977) The depth distributions and community organization of the planktonic cyclopoids (Crustacea: Copepoda) of the Cape Verde Island region. J Mar Biol Assoc UK 57:543-568

Corkett CJ (1984) Observation on development in copepods Crustaceana Suppl 7:150-153

Ferrari FD, Orsi J (1984) Oithona davisae, new species, and Limnooithona sinensis (Burckhardt, 1912) (Copepoda Cyclopoida: Oithonidae) from the Sacramento-San Joaquin estuary, California. J Crustac Biol 4:106-126

Fransz HG, Gonzalez SR (1995) The production of Oithona similis (Copepoda: Cyclopoida) in the Southern Ocean ICES (Int Counc Explor Sea) J Mar Sci 52:549-555

González HE, Smetacek V (1994) The possible role of the cyclopoid copepod Oithona in retarding vertical flux of zooplankton fecal material. Mar Ecol Prog Ser 113: $223-246$

Hirota R (1990) Microdistribution of the marine copepod Oithona davisae in the shallow waters of Ariake-kai mud flats, Japan. Mar Biol 105:307-312

Hirota $R$, Tanaka $Y$ (1985) High abundance of Oithona davisae (Copepoda: Cyclopoida) in the shallow waters adjacent to the mud flats in Ariake-kai, western Kyushu Bull Plankton Soc Jpn 32:169-170

Hopkins TL. Torres JJ (1989) Midwater food web in the vicinity of a marginal ice zone in the western Weddell Sea Deep Sea Res 36:543-560

Huntley M, Lopez MDG (1992) Temperature dependent growth production of marine copepods: a global synthesis Am Nat 140:201-242

Landry MR (1978) Population dynamics and production of a planktonic marine copepod Acartia clausi, in a small temperate lagoon on San Juan Island, Washington. Int Rev Ges Hydrobiol 63:77-120

Lee WY, McAlice BJ (1979) Sampling variability of marine zooplankton in a tidal estuary. Estuar Coast Mar Sci 8: 565-582

Liang D, Uye S (1996a) Population dynamics and production of the planktonic copepods in a eutrophic inlet of the Inland Sea of Japan. II. Acartia omorii. Mar Biol 125:109-117

Liang D, Uye S (1996b) Population dynamics and production of the planktonic copepods in a eutrophic inlet of the Inland Sea of Japan. III. Paracalanus sp. Mar Biol 127: 219-227

Liang D, Uye S (1997) Population dynamics and production of the planktonic copepods in a eutrophic inlet of the Inland Sea of Japan. IV Pseudodiaptomus marinus, the eggcarrying calanoid. Mar Biol 128:415-421

Liang D, Uye S, Onbe T (1996) Population dynamics and production of the planktonic copepods in a eutrophic inlet of the Inland Sea of Japan. I. Centropages abdominalis. Mar Biol 124:527-536

Mullin MM (1988) Production and distribution of nauplii and recruitment variability - putting the pieces together. In: Rothchild BJ (ed) Toward a theory on biological-physical interactions in the world ocean. Kluwer Academic Press, New York, p 297-320 
Nagasawa S, Marumo R (1984) The zooplankton community and its abundance in Tokyo Bay. La Mer 22:277-286

Nakamura Y, Turner JT (in press) Predation and respiration by the small cyclopoid copepod Oithona similis: how important is feeding on ciliates and heterotrophic flagellates? J Plankton Res 19:1275-1288

Nielsen TG, Sabatini M (1996) Role of cyclopoid copepod Oithona spp. in North Sea plankton communities. Mar Ecol Prog Ser 139:79-93

Nishida S (1985) Taxonomy and distribution of the family Oithonidae (Copepoda, Cyclopoida) in the Pacific and Indian Oceans. Bull Ocean Res Inst Univ Tokyo 20:1-167

Paffenhöfer GA (1993) On the ecology of marine cyclopoid copepods (Crustacea, Copepoda). J Plankton Res 15:37-55

Sabatini M, Kiørboe T (1994) Egg production, growth and development of the cyclopoid copepod Oithona similis. J Plankton Res 16:1329-1351

Sameoto DD (1975) Tidal and diurnal effects on zooplankton sample variability in a nearshore marine environment. J Fish Res Bd Can 32:847-866

Shuvalov VS (1975) Geographical variability of some species of the family Oithonidae (Copepoda, Cyclopoida). In: Zvereva ZA (ed) Geographical and seasonal variability of marine plankton. Keter Publishing House Jerusalem Ltd, Jerusalem, p 169-185

Turner JT (1986) Zooplankton feeding ecology. Contents of fecal pellets of the cyclopoid copepods Oncaea venusta, Corycaeus amazonicus, Oithona plumifera and $O$. simplex from the northern Gulf of Mexico. PSZN I: Mar Ecol 7: 289-302

Uchima M (1985) The ecological studies of the marine copepod Oithona davisae Fruchtl, with special reference to its population control. PhD thesis, Univ Tokyo (in Japanese with English abstract)

Uchima M (1988) Gut content analysis of neritic copepods Acartia omorii and Oithona davisae by a new method. Mar Ecol Prog Ser 48:93-97

Editorial responsibility: Otto Kinne (Editor), Oldendorf/Luhe, Germany
Uchima M, Hirano R (1986a) Food of Oithona davisae (Copepoda: Cyclopoida) and the effect of food concentration at first feeding on the larval growth. Bull Plankton Soc Jpn $33: 21-28$

Uchima M, Hirano R (1986b) Predation and cannibalism in neritic copepods. Bull Plankton Soc Jpn 33:147-149

Ueda $H$ (1987) Small-scale ontogenetic and diel vertical distributions of neritic copepods in Maizuru Bay, Japan. Mar Ecol Prog Ser 35:65-73

Ueda $H$ (1991) Horizontal distribution of planktonic copepods in inlet waters. Bull Plankton Soc Jpn Spec Vol:143-160

Uye S (1982) Length-weight relationships of important zooplankton from the Inland Sea of Japan. J Oceanogr Soc Jpn 38:149-158

Uye S (1994) Replacement of large copepods by small ones with eutrophication of embayments: cause and consequence. Hydrobiologia 292/293:513-519

Uye S, Ayaki Y, Onbe T (1992) Seasonal geographical distribution of zooplankton in Hiroshima Bay and its adjacent waters, the Inland Sea of Japan. J Fac Appl Biol Sci Hiroshima Unjv 31:99-119

Uye S, Liang D (in press) Copepods attain high abundance, biomass and production in the absence of large predators but suffer cannibalistic loss. J Mar Syst

Uye S, Sano K (1995) Seasonal reproductive biology of the small cyclopoid copepod Oithona davisae in a temperate eutrophic inlet. Mar Ecol Prog Ser 118:121-128

Uye S, Shibuno (1982) Reproductive biology of the planktonic copepod Paracalanus $\mathrm{sp}$. in the Inland Sea of Japan. J Plankton Res 14:343-358

Yamaguchi Y. Aruga Y (1988) Transition of primary production in Tokyo Bay. Bull Coast Oceanogr 25:87-95 (in Japanese)

Yamazi I (1956) Plankton investigation in inlet waters along the coast of Japan. XIX. Regional characteristics and classification of inlet waters based on the plankton communities. Publ Seto Mar Biol Lab 5:25-61

Submitted: October 2, 1997; Accepted: January 6, 1998 Proofs received from author(s): February 24, 1998 